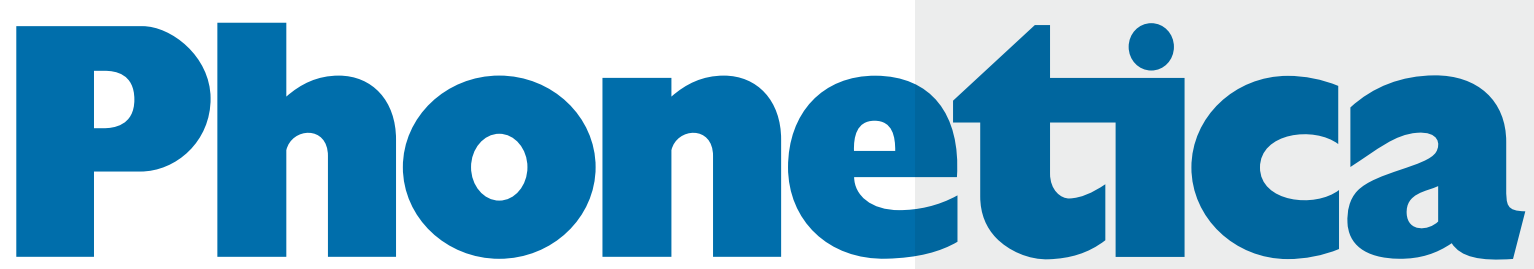

\title{
Bridging the Segment-Prosody Divide in Speech Production and Perception
}

Editor

Klaus J. Kohler, Kiel 


\section{An international journal of communication sciences and disorders}

\section{Folia Phoniatrica et Logopaedica}

International Journal of Phoniatrics, Speech Therapy and Communication Pathology

\section{Editor-n-Chief}

G.Weismer, Madison Wisc.

\section{Associate Editors}

D.-E. Bamiou, London

H.G. Bosshardt, Bochum

T. Klee, Christchurch

M. McAuliffe, Christchurch

P. Paquier, Bruxelles

R. Shrivastav,

East Lansing, Mich.
Official Organ of the International Association of Logopedics and Phoniatrics (IALP)

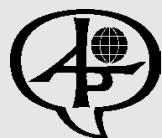

Impact Factor: 1.115

\section{FoliaPhoniatrica et Logopaedica}

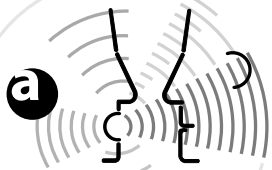

a
More information at

\section{www.karger.com/fpl}

- Pay-per-View and Subscriber Access to Full Text

- Full Table of Contents

- Full Editorial Board

- Free Abstracts and Selected Articles

- Online Sample Issue

- Submission/Guidelines for Authors

- Subscription Details

- Free Alert Service

- Online Library Recommendation

Folia Phoniatrica et Logopaedica 2013: Volume 65

6 issues per volume

Languages: English, German, French

ISSN 1021-7762 (print)

ISSN 1421-9972 (online)

Listed in bibliographic services, including Current Contents ${ }^{\oplus}$, Pubmed/MEDLINE,

Biological Abstracts

\section{Selected contributions}

- Discrimination of Three Basic Female Voice Types in Female Singing Students by Voice Range Profile-Derived Parameters: Lycke, H.; Decoster, W.; Ivanova, A.; Van Hulle, M.M.; de Jong, F.I.C.R.S. (Leuven)

- Recognition of Face Identity and Emotion in Expressive Specific Language Impairment: Merkenschlager, A. (Leipzig); Amorosa, H. (München); Kiefl, H. (Weiden/Oberpfalz); Martinius, J. (München)

- Genetic Bases of Stuttering: The State of the Art, 2011: Kraft, S.J. (Detroit, Mich.); Yairi, E. (Urbana, III.JTel Aviv)

- Effect of Level of Presentation to Listeners on Scaled Speech Intelligibility of Speakers with Dysarthria: Kim, Y. (Baton Rouge, La.); Kuo, C. (Madison, Wisc.)

- Spoken Language Skills and Educational Placement in Finnish Children with Cochlear Implants: Lonka, E.; Hasan, M.; Komulainen, E. (Helsinki)

- Respiratory Changes during Reading in Mandarin-Speaking Adolescents with Prelingual Hearing Impairment: Che, W.-C.; Wang, Y.-T.; Lu, H.-J. (Taipei); Green, J.R. (Lincoln, Nebr.)

- Satisfaction and Quality of Life in Laryngectomees after Voice Prosthesis Rehabilitation: Giordano, L.; Toma, S.; Teggi, R.; Palonta, F.; Ferrario, F.; Bondi, S.; Bussi, M. (Milan)

- Population-Based Screening of Children for Specific Speech and Language Impairment in Germany: A Systematic Review: Kasper, J. (Hamburg); Kreis, J.; Scheibler, F. (Köln); Möller, D. (Hamburg); Skipka, G.; Lange, S. (Köln); von dem Knesebeck, 0. (Hamburg)
Published since 1947, Folia Phoniatrica et Logopaedica provides a forum for international research on the anatomy, physiology, and pathology of structures of the speech, language, and hearing mechanisms. Original papers published in this journal report new findings on basic function, assessment, management, and test development in communication sciences and disorders, as well as experiments designed to test specific theories of speech, language, and hearing function. Review papers of high quality are also welcomed. 


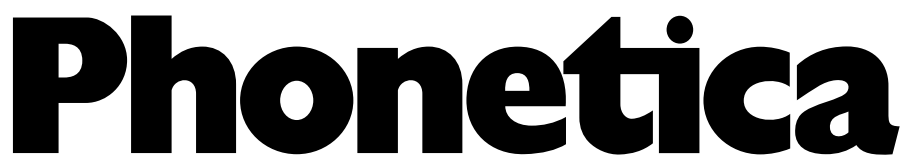

International Journal of Phonetic Science

Founded 1957 by E. Zwirner.

Edited by E. Zwirner 1957-1969, B. Malmberg 1962-1969,

H. Pilch 1962-1978, W. Bethge 1963-1969, G. Ungeheuer 1970-1978.

Redactor 1970-1978 W. Bethge.

\section{General Editor}

Klaus J. Kohler

Universität Kiel

D-24098 Kiel, Germany

E-Mail: kjk@ipds.uni-kiel.de

\section{Associate Editors}

Speech Production and Speaker Characteristics Physiology, Articulation, Acoustics

Daniel Recasens, Barcelona

Jaqueline Vaissière, Paris

Francis Nolan, Cambridge

Speech Perception and Speech Understanding From Signal to Sound Identification and from Sound to Sense

Sarah Hawkins, Cambridge

Vincent J.J.P. van Heuven, Leiden

Sound and Function in Speech Interaction

Oliver Niebuhr, Kiel

Richard Ogden, York

Descriptive Phonetics of the World's Languages

Klaus J. Kohler, Kiel and all Associate Editors

Stress, Tone, and Utterance Prosody

David House, Stockholm

Yi Xu, London

Speech and Language Acquisition

William J. Barry,

Sindlesham-Wokingham

Phonetic Typology, Phonetic Universals, and Sound Change

Klaus J. Kohler, Kiel

Theory, Methodology and History

of Phonetic Science

Klaus J. Kohler, Kiel

Book Reviews

Oliver Niebuhr, Kiel

\section{Editorial Board}

Patrice S. Beddor, Ann Arbor, Mich Andrew Butcher, Adelaide, S.A.

Randy L. Diehl, Austin, Tex.

Olle Engstrand, Stockholm

Nina Grønnum, Copenhagen

Sun-Ah Jun, Los Angeles, Calif.

Hermann J. Künzel, Marburg

Francisco Lacerda, Stockholm

Shinji Maeda, Paris

Kikuo Maekawa, Tokyo

Hartmut Pfitzinger, Kiel

Annie Rialland, Paris

Chilin Shih, Urbana, Ill.

Rachel Smith, Glasgow

Jan-Olof Svantesson, Lund

Marc Swerts, Tilburg

Jan Volín, Prague

Eric Zee, Hong Kong
Printed in Switzerland paper (ISO 9706) by Reinhardt Druck, Basel (4 issues) 


\section{Submission}

Only original papers written in English are considered. They should be submitted electronically as a zip file in an e-mail attachment to:

Prof. Dr. Klaus J. Kohler, Kiel, Germany kjk@ipds.uni-kiel.de

The zip file contains the text of the paper in both PDF and Word format, all fonts embedded, as well as separate files in jpg, tif, or ps format for each figure, indexed fign.xyz. Cf. Tables and illustrations.

\section{Note}

Papers must be as concise as possible. If they are too long they will be returned for shortening.

\section{Conditions}

All manuscripts are subject to editorial review. Manuscripts are received with the explicit understanding that they are not under simultaneous consideration by any other publication. Submission of an article for publication implies the transfer of the copyright from the author to the publisher upon acceptance. Accepted papers become the permanent property of 'Phonetica' and may not be reproduced by any means, in whole or in part, without the written consent of the publisher. It is the author's responsibility to obtain permission to reproduce illustrations, tables, etc. from other publications.

\section{Conflicts of Interest}

Authors are required to disclose any sponsorship or funding arrangements relating to their research and all authors should disclose any possible conflicts of interest. Conflict of interest statements will be published at the end of the article.

\section{Arrangement}

Please arrange your manuscript in font size 12, double-spaced, left-adjusted and with numbered manuscript pages.

Title page: The first page of each paper should indicate the title, the authors' names, the institute where the work was conducted, and a short title for use as running head.

Full address: The exact postal address of the corresponding author complete with posta code must be given at the bottom of the title page. Please also supply phone and fax numbers, as well as e-mail address.

Abstract: Each paper needs an abstract of up to 10 lines.

\section{Footnotes: Avoid footnotes.}

Tables and illustrations: Tables and illustrations (both numbered in Arabic numerals) should be prepared on separate pages. Table require headings, figures legends; all table headings are collectively listed on a separate page, and likewise all figure legends. The tables, and the two lists of headings and legends are appended to the text file. Figures are not to be included in the text but submitted in separate files for each figure. $\mathrm{B} / \mathrm{w}$ half-tone and color illustrations must have a final resolution of $300 \mathrm{dpi}$ after scaling, line drawings one of $800-1,200 \mathrm{dpi}$.

\section{Color illustrations}

Online edition: Color illustrations are reproduced free of charge. In the print version, the illustrations are reproduced in black and white. Please avoid referring to the colors in the text and figure legends.

Print edition: Up to 6 color illustrations per page can be integrated within the text at $\mathrm{CHF}$ 800.- per page.

References: The list of references should in clude only those publications which are cited in the text. References should be arranged alphabetically (citation by name and year).

\section{Examples}

a) Papers published in periodicals:

1. All authors' surnames ('et al.' is not sufficient) with initials of first names; 2 . Full title of paper; 3. Journal abbreviation; 4. Volume (in Arabic numerals, underlined and followed by a colon); 5 . First and last page 6. Year of publication in parentheses. Example: Sternberg, S.; Knoll, R.L.; Monsell, S. Wright, C.E.: Motor programs and hierarchical organization in the control of rapid speech. Phonetica 45: 175-197 (1988).

b) Books:

1. Authors' surnames with initials of first names; 2. Full title; 3. In parentheses, name and domicile of publisher and year of publication. Example: Zwirner, E.; Zwirner, K.: Grundfragen der phonometrischen Linguistik (Karger, Basel 1981).

\section{Supplementary Material}

Supplementary material is restricted to additional data that are not necessary for the scientific integrity and conclusions of the paper. Please note that all supplementary files will undergo editorial review and should be submitted together with the original manuscript. The Editors reserve the right to limit the scope and length of the supplementary material. Supplementary material must meet production quality standards for Web publication without the need for any modifica- tion or editing. In general, supplementary files should not exceed $10 \mathrm{MB}$ in size. All figures and tables should have titles and legends and all files should be supplied separately and named clearly. Acceptable files and formats are: Word or PDF files, Excel spreadsheets (only if the data cannot be converted properly to a PDF file), video files (.mov, .avi, .mpeg), and audio files (.wav), either free standing or incorporated into html or ppt files, in each case to illustrate the sound of speech. Accepted supplementary material will be published as submitted and no proofs will be provided to the authors.

\section{Digital Object Identifier (DOI)}

S. Karger Publishers supports DOIs as unique identifiers for articles. A DOI number will be printed on the title page of each article. DOIs can be useful in the future for identifying and citing articles published online without volume or issue information. More information can be found at www.doi.org.

\section{Author's Choice ${ }^{\mathrm{TM}}$}

With this option the author can choose to make his article freely available online against a one-time fee of CHF 3000.-. This fee is independent of any standard charges for supplementary pages, color images etc. which may apply. More information can be found at www.karger.com/authors_choice. Does your funding agency/institute require you to deposit your article in an institutional archive (e.g. PubMedCentral)? You will be pleased to hear that Karger journals are fully geared up for this requirement. All you have to do is opt for open access publication of your article through Karger's Author's Choice $^{\mathrm{TM}}$. Karger will also take care of the immediate deposit in the PubMedCentral archive and what's more, not of the manuscript, but of the final, published article. The article will also be available with open access right away, and not just after 12 months. The cost of Author's Choice ${ }^{\mathrm{TM}}$ is a permissible cost in your grant, so please take care to budget for it.

\section{Proofs}

Unless indicated otherwise, proofs are sent to the corresponding author and should be returned with the least possible delay. Alterations other than the correction of printer's errors are charged to the author.

\section{Reprints}

The senior author will receive 50 reprints free of charge. For additional reprints, order forms and a price list are sent with the proofs. Orders submitted after the issue is printed are subject to considerably higher prices.

\section{KARGER}

Fax +41 613061234

E-Mail karger@karger.ch www.karger.com
(C) 2012 S. Karger AG, Basel

The Guidelines for Authors are available at: www.karger.com/pho_Guidelines 
ISSN Print Edition: 0031-8388 ISSN Online Edition: 1423-0321

Journal Homepage: www.karger.com/pho

Publication Data: 'Phonetica' is published 4 times a year. Volume 69 with 4 issues appears in 2012.

Copyright: () 2012 S. Karger AG, Basel (Switzerland). All rights reserved. No part of this publication may be translated into other languages, reproduced or utilized in any form or by any means, electronic or mechanical, including photocopying, recording, microcopying, or by any information storage and retrieval system, without permission in writing from the publisher or, in the case of photocopying, direct payment of a specified fee to the Copyright Clearance Center.

Disclaimer: The statements, opinions and data contained in this publication are solely those of the individual authors and contributors and not of the publisher and the editor(s). The appearance of advertisements in the journal is not a warranty, en dorsement, or approval of the products or services advertised or of their effectiveness, quality or safety. The publisher and the editor(s) disclaim responsibility for any injury to persons or property resulting from any ideas, methods, instructions or products referred to in the content or advertisements.
Subscription Rates: Subscriptions run for a full calendar year. Prices are given per year. Personal subscription:

Print or Online Print+Online combined

CHF 300.- $\quad$ CHF 348.-

EUR 240.- $\quad$ EUR 278.-

USD $291.00 \quad$ USD 338.00

postage and handling (added to print and print+online)

CHF 27.20 Europe, CHF 40.- Overseas

EUR 20.80

USD 37.60

Institutional subscription:

Print or Online

Print+Online combined

CHF 1199.-

EUR 959.-

CHF 1319.

USD 1164.00

EUR 1055.-

postage and handling (added to print and print+online)

CHF 34.- Europe, CHF 50.- Overseas

EUR 26.-

USD 47.00

Airmail surcharge: CHF 34.- / USD 32.00
Back Volumes and Single Issues: Information on availability and prices of single print issues and print or electronic back volumes can be obtained from Customer Service at service@karger.ch.

Bibliographic Indices: This journal is regularly listed in bibliographic services, including Current Contents $^{\circledR}$ and PubMed/MEDLINE.

Photocopying: This journal has been registered with the Copyright Clearance Center (CCC), as indicated by the code appearing on the first page of each article. For readers in the US, this code signals consent for copying of articles for personal or internal use, or for the personal or internal use of specific clients, provided that the stated fee is paid per copy directly to

Copyright Clearance Center Inc.

222 Rosewood Drive

Danvers, MA 01923 (USA)

A copy of the first page of the article must accompany payment. Consent does not extend to copying for general distribution, for promotion, for creating new works, or for resale. In these cases, specific written permission must be obtained from the copyright owner,

S. Karger AG, P.O. Box

CH-4009 Basel (Switzerland).

\begin{tabular}{|c|c|c|c|}
\hline \multirow[t]{2}{*}{$\begin{array}{l}\text { Subscription Orders: } \\
\text { Orders can be placed at agencies, } \\
\text { bookstores, directly with the Publisher }\end{array}$} & \multirow[t]{2}{*}{$\begin{array}{l}\text { or further Karger offices } \\
\text { or representatives: }\end{array}$} & $\begin{array}{l}\text { USA } \\
\text { S. Karger Publishers, Inc. } \\
26 \text { West Avon Road }\end{array}$ & $\begin{array}{l}\text { South East Asia, China and Taiwan } \\
\text { Karger Regional Office (Malaysia) } \\
\text { CEO Suite Kuala Lumpur }\end{array}$ \\
\hline & & P.O. Box 529 & $\begin{array}{l}\text { Quill 7,27th Floor } \\
\text { Plp }\end{array}$ \\
\hline S. Karger AG & \multirow{7}{*}{$\begin{array}{l}\text { Germany } \\
\text { S. Karger GmbH } \\
\text { Postfach } \\
\text { 79095 Freiburg } \\
\text { Deutschland } \\
\text { (Hausadresse: Wilhelmstrasse 20A, } \\
\text { 79098 Freiburg) } \\
\text { t: }+49761452070\end{array}$} & Unionville, CT 06085 & Jalan Stesen Sentral 5 \\
\hline Medical and Scientific Publishers & & USA & KL Sentral \\
\hline P.O. Box & & Toll free: +18008285479 & Kuala Lumpur 50470 \\
\hline CH-4009 Basel & & $\mathrm{t}: \quad+18606757834$ & Malaysia \\
\hline Switzerland & & $\mathrm{f}: \quad+18606757302$ & $\mathrm{t}:+60327766803$ \\
\hline (for courier services only: & & e: karger@snet.net & f: +60327766999 \\
\hline Allschwilerstrasse 10 & & & e: service@karger.cn; r.chew@karger.cn \\
\hline CH-4055 Basel) & $\mathrm{f}: \quad+497614520714$ & France & \\
\hline $\mathrm{t}: \quad+41613061111$ & e: information@karger.de & Librairie Médi-Sciences Sarl & Karger China \\
\hline f: +41613061234 & w: www.karger.de & 36, bd de Latour-Maubourg & 10th Floor, Twin Towers (East) \\
\hline e: karger@karger.ch & & 75007 Paris & B12 Jianguomenwai Avenue \\
\hline w: www.karger.com & Japan & France & Beijing 100022 \\
\hline & Karger Japan, Inc. & $t: \quad+33(0) 145514258$ & China \\
\hline & Shiba Daimon Asahi Bldg. 2F & $\mathrm{f}: \quad+33(0) 145560780$ & $\mathrm{t}: \quad+861051235033$ \\
\hline & 1-2-23 Shiba Daimon & e: librairie@medi-sciences.fr & $\mathrm{f}: \quad+861051235122$ \\
\hline & $\begin{array}{l}\text { Minato-ku } \\
\text { Tokyo } 105-0012\end{array}$ & w: www.medi-sciences.fr & e: service@karger.cn; r.chew@karger.cn \\
\hline & $\begin{array}{l}\text { Jopan } \\
\text { Jas-0012 }\end{array}$ & Gulf Council Countries, Iran, & w: www.karger.cn \\
\hline & $\mathrm{t}:+81364356242$ & Middle East, North Africa, Turkey & India, Bangladesh, Sri Lanka \\
\hline & $\begin{array}{l}\text { f: }+81364356244 \\
\text { e: publisher@karger.jp }\end{array}$ & & Medscience India \\
\hline & w: www.karger.jp & $\begin{array}{l}\text { Distribution Co. Ltd. (KaSha) } \\
168 \text { B, King Abdullah the 2nd Street }\end{array}$ & $\begin{array}{l}\text { Plot No. 17, Yusut Sara1 Market } \\
\text { B.L. Glass Building, 2nd Floor }\end{array}$ \\
\hline & & Daboog Building 2nd Floor & Sri Aurobindo Marg \\
\hline & & Daboog Area & New Delhi $110016^{\circ}$ \\
\hline & & P.O. Box 2376 & India \\
\hline & & Amman 11953 & $\mathrm{t}: \quad+911146029633$ \\
\hline & & Jordan & $\mathrm{f}: \quad+911146029634$ \\
\hline & & $t:+96265153467$ & c: +919891052128 \\
\hline Change of Address: & & f: +96265411336 & e: medsci.india@gmail.com \\
\hline Both old and new address should be sent & & e: info@kasha.cc & \\
\hline to the subscription sourc & & w: www.KaShaonline.com & \\
\hline
\end{tabular}

KARGER

Fax +41613061234

E-Mail karger@karger.ch www.karger.com
(C) 2012 S. Karger AG, Basel

The Journal Home Page is available at: www.karger.com/pho 


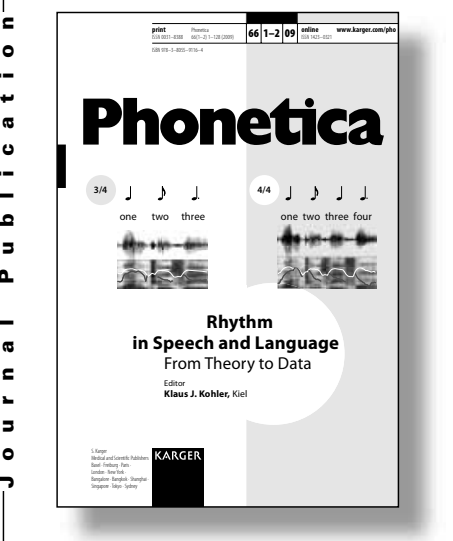

Contents

\section{Editorial}

Whither Speech Rhythm Research? Kohler, K.J.

\section{Original Papers}

Rhythm as an Affordance for the Entrainment of Movement: Cummins, $\boldsymbol{F}$

Rhythm in Speech and Language. A New Research Paradigm: Kohler, K.J.

Rhythm, Timing and the Timing of Rhythm:

\section{Arvaniti, $A$.}

The Pairwise Variability Index and Coexisting Rhythms in Language: Nolan, F.; Asu, E.L.

Do Rhythm Measures Reflect Perceived

Rhythm? Barry, W.; Andreeva, B.;

Koreman, $\mathbf{J}$.

Fundamental Frequency-Based Rhythm Effects on the Perception of Local Syllable Prominence: Niebuhr, $\boldsymbol{O}$.

On the Possible Role of Brain Rhythms in Speech Perception: Intelligibility of Time-Compressed Speech with Periodic and Aperiodic Insertions of Silence: Ghitza, $\mathbf{0}$; Greenberg, S.

Index autorum

\section{Rhythm in Speech and Language From Theory to Data}

\author{
Editor \\ Klaus J. Kohler
}

What are the differences of rhythm in the production and perception of speech in speaking styles and languages? What are the physical manifestations and functions of rhythm in speech interaction? In this volume, seven papers by speech scientists from research fields and institutions across the world of phonetic science provide answers to these questions.

The contributions give a survey of past experimental investigations, present data of recent analyses, and propose new directions for the future of rhythm research. The main focus lies on the entrainment of movement, the listener's active role in speech perception, as well as the guiding function in speaker-listener interchange. The new data of rhythm research include analyses of production patterns in Bulgarian, English, Estonian, German, Greek and Spanish, as well as corresponding perceptual experiments and links to physiological brain rhythms.

The rhythmical structuring of speech in the languages of the world is significant for phoneticians, general linguists, philologists, psychologists, speech therapists and speech technologists.

www.karger.com/pho

\section{Phonetica}

Editor: Kohler, K.J. (Kiel)

ISSN 0031-8388 / e-ISSN 1423-0321

Special issue: Vol. 66, No. 1-2 (2009)

Included in subscription

Rhythm in Speech and Language

Editor: Kohler, K.J. (Kiel)

128 p., 26 fig., 13 tab., soft cover, 2009

CHF 45.- / EUR 32. - / USD 45.00

Prices subject to change

EUR price for Germany, USD price for USA only

ISBN 978-3-8055-9116-4

e-ISBN 978-3-8055-9117-1

KARGER
Please send:__ copy/ies

Postage and handling free with prepayment

E Payment:

- Please charge to my credit card

- $\square$ American Express $\square$ Diners $\square$ Eurocard

ᄂ $\square$ MasterCard

- Card No

๑

- Exp. date:

- $\mathrm{CVV} / \mathrm{CVC}$

(3 digits in the signature field on the back of Visa and MasterCard)

$\square$ Check enclosed $\quad \square$ Please bill me

Orders may be placed with any bookshop, subscription agency, directly with the publisher or through a Karger distributor.
Fax: +41 613061234

S. Karger AG, P.O. Box, CH-4009 Basel (Switzerland)

E-Mail orders@karger.ch, www.karger.com

Name/Address:

Date

Signature: 


\section{Contents}

See the journal website for contents

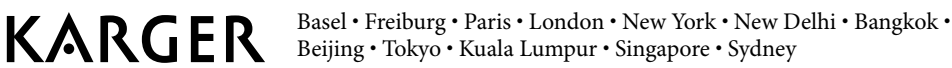




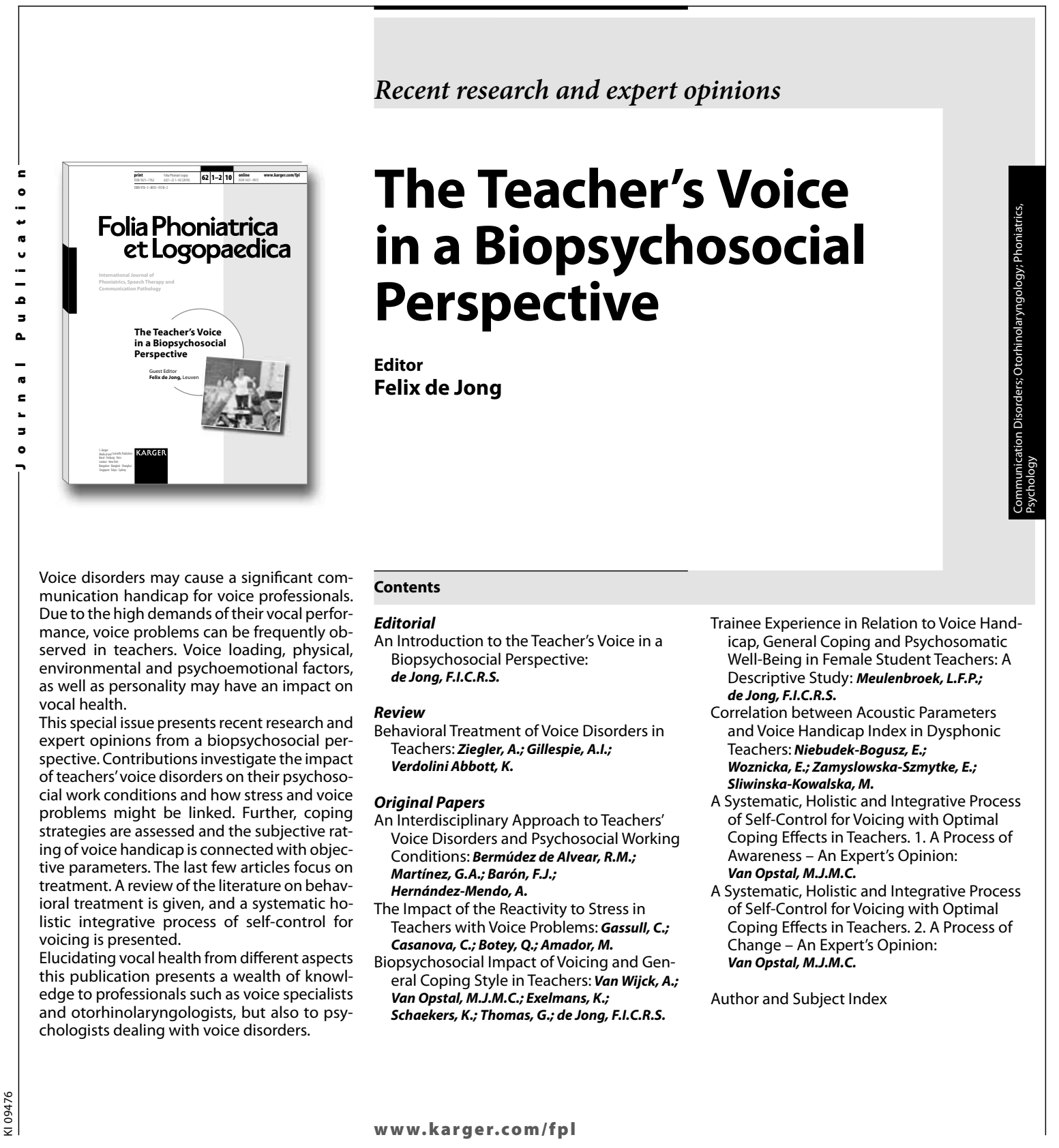

Folia Phoniatrica et Logopaedica Editor: Schutte, H.K. (Groningen) ISSN 1021-7762/ e-ISSN 1421-9972 Special issue: Vol. 62, No. 1-2 (2010)

The Teacher's Voice in a Biopsychosocial Perspective

Editor: de Jong, F.I.C.R.S. (Leuven)

86 p., 5 fig., 21 tab., soft cover, 201

CHF 39.- / EUR 32.- / USD 46.00

Prices subject to change

EUR price for Germany, USD price for USA only

ISBN 978-3-8055-9318-2

e-ISBN 978-3-8055-9319-9

\section{KARGER}

Please send: __ copy/ies Postage and handling free with prepayment

Payment:

- Please charge to my credit card

- $\square$ American Express $\square$ Diners $\square$ Eurocard

ᄂ $\square$ MasterCard $\square$ Visa

- Card No.:

ช

- CVV/CVC

( 3 digits in the signature field on the back of Visa and MasterCard)

$\square$ Check enclosed $\quad \square$ Please bill me

Orders may be placed with any bookshop, subscription agency, directly with the publisher or through a Karger distributor.
Fax: +41 613061234

S. Karger AG, P.O. Box, CH-4009 Basel (Switzerland) E-Mail orders@karger.ch, www.karger.com

Name/Address:

Date:

Signature: 


\section{Phonetica}

\section{Bridging the Segment-Prosody Divide in Speech Production and Perception}

Phonetic expression is generally divided into sounds and prosodies. This collection of articles focuses on the interrelation of the two domains.

Descriptive and experimental techniques are applied in speech production and perception to analyze sounds in different prosodic patterns, and prosodic patterns across different sounds at the levels of intonation, tone, emphatic intensification, lexical stress and foreign-accented speech. One of the striking results is that German fricatives /f/, $/ \mathrm{s} /$, $/ \int /, / x /$ are produced with higher-spectral energy distribution in high-rising than in falling $\mathrm{fo}$ contours, and that the same fricative types in the two different prosodies sound high- versus low-pitched, and thus heighten the perception of the rising or falling intonation. The publication will be basic reading for anybody interested in bridging the separation into segments and prosodies, thus acquiring a more complete picture of human speech: phoneticians, linguists, applied linguists, psycholinguists, psychologists, speech-technologists as well as foreign-language teachers. 